\title{
American Trade Unions and Public Approval: Can Unions Please All of the People All of the Time?
}

\author{
PAUL JARLEY \\ Louisiana State University \\ SAROSH KURUVILLA \\ School of Industrial Labor Relations, Cornell University
}

Public opinion about labor unions has long been viewed as an important determinant of industrial relations outcomes. Yet, analyses of changes in union popularity over time have been largely qualitative and have focused on the impact of short-term idiosyncratic events. This paper provides a quantitative analysis of the determinants of American public approval of unions from 1936 to 1991. Hypotheses relating to the union wage advantage, strike activity, the national unemployment rate, and World War II, receive the strongest support. The implications of these results for organized labor and future research on attitudes toward unions are discussed.

\section{Introduction}

Since the 1930s, pollsters have questioned Americans about their views on labor unions. Public comment has been sought on the right to form unions, the honesty and integrity of union leaders, the appropriateness of union activities (e.g., featherbedding and strikes), and the extent of union power in America. More frequently, the public has been asked to provide a bottom-line assessment of the U.S. labor movement, generating the often-cited "union approval rating" - the percent of respondents who report their approval of labor unions. Results of these polls are prominently reported in the press and both labor and management partisans tend to view movements in the union approval rating as a sign of changing public support for organized labor (e.g., Anonymous, 1988, p. 1). The long decline in the union approval rating contributed to the AFL-CIO's Committee on the Evolution of Work's (1985) recommendation that better efforts be made to publicize labor's contribution to workers and society. The AFL-CIO responded with the "Union Yes Campaign," devoting over \$13 million to the effort in 1988 and 1989 alone (Kirkland, 1988). 
Scholars have also viewed polling data with great interest. Bok and Dunlop (1970, p. 11) argue that public opinion represents "an important force affecting the process of labor relations and the activities of labor organizations." They assert that public opinion can enhance or impede union political activity, influence member loyalty, and affect how employers deal with unions. The argument is advanced more forcefully by Lipset (1986), who views the public's approval of unions as a primary force influencing unions' ability to win representation elections and the level of union membership generally. Support for Lipset's assertion is provided by Stepina and Fiorito (1986, p. 259) who report a positive and significant relationship between the union approval rating and the relative change in union membership from 1947 to 1982.

Despite the interest in the level of public support for organized labor, there exists little quantitative work on the determinants of public approval of labor unions. This paper addresses this gap in the literature by testing a model of the union approval rating. We proceed as follows. Section II summarizes the evidence on public opinion about trade unions in the United States and reviews empirical work on movements in the union approval rating. Section III presents the data on union approval in the United States and makes some preliminary observations concerning the trend in union popularity from 1936 to 1991 . Section IV outlines a framework for understanding how such opinions about unions are formed and specifies an empirical model. The results in Section $\mathrm{V}$ suggest that union approval is sensitive to several factors, including strike activity, macroeconomic conditions, and the union wage advantage. The final section offers concluding comments.

\section{Prior Research on Union Popularity}

Most public opinion surveys are conducted on behalf of news agencies. Questions tend to focus on specific issues, individuals, or institutions that have captured the media's attention. Because institutions tend to outlive specific issues and individuals, questions assessing union popularity are asked over a longer period of time than those pertaining to such topics as the legality of strikes or the popularity of a certain labor leader. Measures of union popularity vary somewhat depending on the polling organization (e.g., Gallup's Union Approval Rating; the National Election Survey's Union Feelings Thermometer; Harris' Unions are Helpful (Harmful) to the Country question), but all are believed to tap the public's global assessment of unions' roles and functions in contemporary society (Lipset and Schneider, 1983, p. 201). Although measures such as the Union Feelings Thermometer provide a metric of the depth of the respondent's attitude toward unions, the longevity of Gallup's Union Approval Rating 
typically makes it the measure of choice in studies that examine movements in public support for unions over time.

A diverse group of questions relate to specific labor issues and events. Craft and Abboushi (1983) classify these items into five core areas: (1) union instrumentality - the degree to which unions are believed to be a means for employees to attain desired work ends; (2) leadership - public perception of persons filling union leadership roles; (3) external power - union influence on national economic outcomes, such as inflation and competitiveness, as well as on political outcomes, such as elections or legislative agendas; (4) internal governance - the fairness of union internal procedures and the extent to which unions are democratic; and (5) membership identity - popular perception of the characteristics and orientations of union members.

Scholarly work has tended to use opinion data to create a mosaic of the public's view of unions. Authors, such as Bok and Dunlop (1970), Lipset (1986), and Lipset and Schneider (1983, p. 220), emphasize the portrait's contrasts. They note that, although a majority of the public typically approves of unions and believes that they are effective in representing their members' interests, many also believe that unions are too powerful and self-serving, engage in too many costly strikes, and have leaders who are untrustworthy and deserving of little confidence. To paraphrase David Marsh (1990), the general impression one gets from these reviews is that the public seems to like unions well enough, but prefers that they be bound and gagged.

How can the public approve of unions in general while expressing such concern about virtually every union attribute? The public's seemingly contradictory view about unions has not been the subject of much quantitative analysis. Cross-sectional work on individuals' assessments of unions provide few clues since these studies focus almost exclusively on the role of individual differences such as occupation, union membership, gender, and party identification (e.g., Krahn and Lowe, 1984, pp. 15659). Longitudinal analyses tend to be qualitative. The public's general support for unions is assumed "to be rooted in a conviction that they are necessary to enable workers to receive improvements in wages and working conditions" (Box and Dunlop, 1970, p. 13). Movements in public approval are viewed as the result of strike activity or other short-term events generally thought to lower public support for unions (e.g., stories about corruption).

Quantitative analyses of longitudinal data on U.S. public approval of unions offer limited insights. Lipset and Schneider (1983, p. 64) examine the macroeconomic determinants of public confidence in union leaders, a concept related to union popularity. Analyzing data from 1966 to 1980, they report a negative and significant effect for the national unemployment rate. Schmidt (1993) 
performs a content analysis of the New York Times from 1947 to 1985, creating two variables that assess the percentage of stories about unions that focus on strikes. Regressing the aggregate union disapproval rating and the disapproval ratings for five subsets of the population on these two measures, she reports positive and generally statistically significant coefficients on the lagged strike coverage measure across equations. The pre-survey strike coverage measure performs less well, yielding coefficients that fail to achieve standard levels of statistical significance in the aggregate dependent variable and a majority of the disaggregated dependent variable equations. These results lead Schmidt (1993, p. 162) to conclude that strike-centered media coverage of unions negatively affects public attitudes about unions over time.

A more extensive effort to examine the determinants of movements in aggregate union popularity over time is provided by Edwards and Bain (1988). Since 1954, the British public has been asked: "Generally speaking and thinking of Britain as a whole, do you think that trade unions are a good thing, or a bad thing?" Using responses to this item for the 1954 to 1985 period, Edwards and Bain specify and test various models of net union popularity (the percent saying unions are a good thing minus the percent saying they are a bad thing) that focus on macroeconomic conditions (e.g.. unemployment and inflation), union influence on government, changes in union membership, and strike activity. They report that over fifty percent of the variance in their net union popularity measure can be explained by just two factors: changes in consumer prices and the number of days lost due to strikes. No other variable reaches standard levels of statistical significance. Edwards and Bain (1988, p. 323) interpret these results to mean that the public in Great Britain is generally supportive of unions, but doesn't care for the tactics unions must use to meet their objectives (i.e., strikes) or some of the consequences that union gains may have for society as a whole (i.e., inflation).

Thus, there is a general agreement on a succinct explanation for changes in union popularity over time. Assuming the dependent variables used in these studies are reasonably valid measures of public support for organized labor (a fact disputed by some, e.g.. Marsh, 1990), changes in such support are a function of changes in macroeconomic conditions and strike activity or media reporting about strikes, or both. 'Yet, these studies share characteristics that leave room to question this basic finding. First, each study fails to systematically consider how individuals process information about unions when arriving at general assessments of the labor movement. Without the benefit of such a coherent theoretical framework, it is difficult to assess the adequacy of their empirical specifications. Using the Craft and Abboushi (1983) typology, it is clear that the quantitative work to date has emphasized the 
external power dimension of union beliefs. Beliefs about union instrumentality, leadership, internal governance, and rank-and-file members have been largely ignored.

Second, both Schmidt (1993) and Edwards and Bain (1988) tend to measure their independent variables at yearly intervals. Public opinion about labor unions is typically assessed for a week or two out of the year. Very short-term events near the interview window may have a significant impact on assessments of union approval (Rosier and Little, 1986). Yearly measures may obscure such effects. Only Schmidt's (1993, p. 159) pre-survey media coverage variable attempts to capture such short-term effects, but her discussion does not reveal the mean interval between her assessment of pre-survey media coverage of strikes and the start of Gallup's interview period.

Finally, there is the issue of external validity. Schmidt's (1993) analysis is limited to the post TaftHartley Act era. Whether strike-centered media coverage has a similar impact on union popularity prior to 1947 or after 1985 is not known. Similarly, the Edwards and Bain results may have limited generalizability to public opinion on' unions in other countries. Unions in the U.S. and U.K. share many characteristics, but they also differ on a number of dimensions (e.g., formal ties to a political party). Such differences in union characteristics may lead to different determinants of public approval of unions across countries.

\section{Trends in Public Approval of Unions}

Figure 1 plots the percentage of respondents stating they approve or disapprove of unions over time. In addition to responses to Gallup surveys (Gallup, various years; Cantril, 1951), data are taken from two comparable ABC News-Washington Post polls (1982, 1986). Gallup's question has changed slightly over time. From 1936 to 1946, "Are you in favor of labor unions?" was used. Since 1947, the question reads: "In general, do you approve or disapprove of labor unions?" Although not readily apparent from an examination of Figure 1, the union approval question is asked at irregular intervals. Gaps of up to five years exist between two adjacent data points (1972 and 1978), while the question was asked multiple times in five different years, including three times in 1957. The interview period is rarely more than two weeks long and the question has been asked in every month except March, the most popular month being May $(n=8)$. 


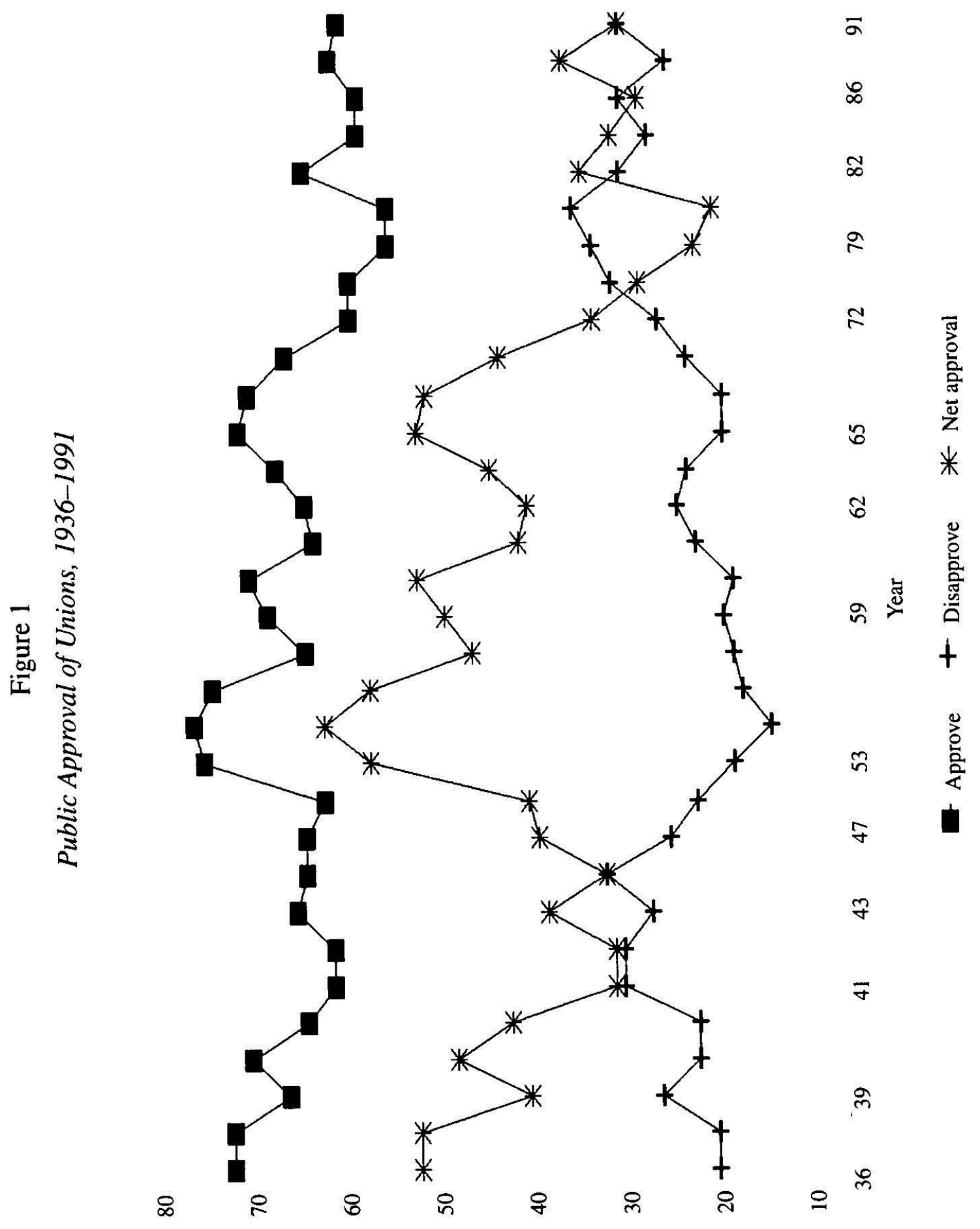

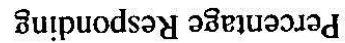


To those unfamiliar with the data reported in Figure 1, the popularity of labor unions might be somewhat surprising. The percentage of respondents who state that they disapprove of unions has rarely exceeded 30 percent and reached a peak of 35 percent in 1981. Public approval of labor unions has never dropped below 55 percent. Even during times when public debate led to legislation that curbed labor's power (the late 1940s) or tried to reduce corruption in trade unions (the late 1950s), labor's public approval rating remained high. In addition, union popularity appears to have improved somewhat during the 1980 s, despite the election of a popular president whose policies were widely viewed as anti-labor. Note that increases in the union approval (or disapproval) rating may come at the expense of the no opinion category which varies from 4 to 18 percent over the period under study. Given that the trend in union disapproval is not the mirror image of the trend in union approval, both trends are of interest and can be modeled separately.

Finally, Figure 1 plots the trend in net union approval (approval minus disapproval), the measure employed by Edwards and Bain (1988). Because the approval and disapproval ratings tend to move in opposite directions, the net approval rating shows more volatility than either of its elements, ranging from a high of 62 percent in January 1957 to a low of 20 percent in August 1981.

\section{Influences on Public Approval of Trade Unions}

How do individuals arrive at an overall assessment of the labor movement? According to Fishbein and Ajzen (1981), individuals form beliefs about an object (hereinafter specifically unions) by associating the object with certain characteristics. An individual comes to believe that unions possess certain characteristics through personal experience with labor unions or by obtaining information about unions from others (e.g., family, friends, or the media). Each characteristic is evaluated as favorable or unfavorable by the individual and is accorded a certain weight in the determination of an overall assessment of labor unions. Thus, to "approve" of unions is to make an assessment that the weighted sum of beliefs about organized labor's positive attributes is greater than the absolute value of the weighted sum of beliefs about its negative attributes. The union approval rating reports the percentage of individuals for whom this is the case.

Applying the Fishbein and Ajzen framework to changes in the union approval rating over time suggests that movements in this index may come from three different sources. First, unions may change their attributes. Unions may rid themselves of unfavorable characteristics (e.g., corrupt leaders or featherbedding practices), or acquire favorable characteristics (e.g., greater internal democracy) which, 
if perceived by the general public, would likely increase the percentage of individuals who state that they approve of unions. Second, union attributes may remain constant, but the public may perceive changes in union characteristics because information sources have changed or the same information sources are now stressing different aspects of unions. For example, as the percentage of workers who are members of labor organizations declines, the dominant source of information about trade unions may shift from personal experience to the experiences of friends and coworkers or media reports about union activities. Should these sources stress information about different union attributes (e.g., it has been argued that the press tends to stress the negative aspects of unions (Craft and Abboushi, 1983, p. 301)), some union attributes may fade from the public mind while others may become more salient. Third, individuals may change their evaluation of a given union characteristic. Experience may show a given attribute to have more positive (or negative) consequences than previously believed or contextual changes may force a revaluation of a given attribute. For example, strikes may be viewed more negatively during war than in peacetime.

Opinion poll data do not permit an assessment of the relative importance of these sources of potential change in public approval of unions over time. Questions assessing respondents' beliefs about various union attributes are asked sporadically and rarely in conjunction with the approval item. Information on how respondents acquire knowledge about trade unions is also absent from the polling data. Thus, we cannot directly examine whether beliefs about union attributes changed over time, nor can we identify changes in beliefs about unions that were the result of changes in information sources about unions.

It is possible, however, to identify changes in union attributes over time. Time series data are available for some important union "attributes" (e.g., strike activity and the union wage advantage), as well as for macroeconomic outcomes partly attributed to union behavior (e.g., unemployment and inflation). It is also possible to examine popular press accounts of major industrial relations events (i.e., union activities) in close proximity to polling on union approval. Thus, our approach assumes that changes in union attributes lead to corresponding changes in public beliefs about union characteristics. Changes in beliefs lead to changes in union approval. In theory, such an approach would also allow for a crude test of changes in the importance of various union attributes in the determination of approval over time, but the limited number of observations available for analysis renders formal tests for differences in coefficients over time impractical. The union attributes and activities included in our analysis are discussed below. 
Strike Activity. Perhaps the most visible trade union activity is the strike. Many commentators have noted that strikes tend to inconvenience the public and may produce wage settlements that are thought to be inflationary (e.g., Lipset and Schneider, 1983, p. 215; Heshizer, 1985, p. 266). In addition, analyses of public opinion polls suggests that the public generally supports reasonable initiatives designed to reduce Strike activity. ${ }^{i i}$ Thus, strike activity is expected to have a negative impact on union approval. Following Edwards and Bain (1988), our strike measure is total working days lost to strikes (Bureau of Labor Statistics, 1983, 1989). Of the three standard measures of strike activity - frequency, workers involved, and days lost - this measure gives greatest weight to long strikes involving many workers, those most likely to capture the public's attention. Consistent with Roiser and Little's (1986) view that public opinion is sensitive to short-term events, days lost in the month prior to the interview period are used.iii This procedure also eliminates problems associated with using calendar-year measures of strike activity when the interview dates for the dependent variable vary considerably within the calendar year. ${ }^{\mathrm{iv}}$

Union Wage Advantage. It is clear from an examination of the voting intent literature that workers are more likely to support unions that are effective (Kochan et al., 1986, pp. 216-17). Although no comprehensive measure of trade union workplace effectiveness exists, it is possible to piece together crude estimates of the union wage premium over the period under study. These estimates are provided by Johnson (1984) for five-year periods from 1920 to 1979 and were augmented for the 1980s by estimates from Blanchflower and Freeman (1992). ${ }^{\vee}$ Although these estimates lack the proximity to the interview period that exists for the strike measure, it seems reasonable to assume that the union wage advantage is more stable than strike activity and that public perception about the union wage advantage changes more slowly than public perception about strike activity. Although we hypothesize that the public is more likely to hold positive attitudes toward effective, rather than ineffective unions there is evidence from the 1980 s suggesting that a majority of the public viewed union gains as excessive. ${ }^{\text {vi }}$ As a result, we allow for the possibility that the relationship between the union wage premium and public approval is nonlinear.

Macroeconomic Conditions. As economic institutions, unions have significant influences on the economy. As a result, unions are likely to take part of the credit (or blame) for existing economic conditions (Lipset and Schneider, 1983, p. 63). Both rising unemployment and inflation may be viewed as the product of union greed and both are expected to have a negative impact on the union approval rating. Our measure of unemployment is the national civilian unemployment rate in the month prior to the interview period \{Monthly Labor Review, various issues). Inflation is measured by the annualized 
change in the consumer price index for the month prior to the interview period (Monthly Labor Review, various issues).

News Stories. Against the backdrop of the national economy, the union wage advantage, and the level of industrial conflict, public opinion polling may take place in the context of a major industrial relations event. Labor relations events, particularly strikes (Raskin, 1991, p. 96; Schmidt, 1993), are routinely reported by the media, but only a select few make the front page, rather than the business page.

Table 1

Major News Stories Concerning Organized Labor in Close Proximity to Union Approval Polling

\begin{tabular}{|c|c|c|c|}
\hline $\begin{array}{l}\text { Interview } \\
\text { Date }\end{array}$ & News Event & $\begin{array}{c}\text { Public } \\
\text { Polled About }\end{array}$ & Variable \\
\hline \multirow[t]{2}{*}{$6 / 36$} & Steel Organizing Drive & No & Disputes \\
\hline & AFL-CIO Split & No & Leaders \\
\hline $5 / 39$ & $\begin{array}{l}\text { Communists in Unions } \\
\text { (e.g., Harry Bridges) }\end{array}$ & No & Leaders \\
\hline $11 / 39$ & Communists in Unions & No & Leaders \\
\hline \multirow[t]{2}{*}{$5 / 41$} & $\begin{array}{l}\text { Communists in Unions and role in } \\
\text { defense industry strikes }\end{array}$ & Yes & $\begin{array}{l}\text { WWII } \\
\text { Leaders }\end{array}$ \\
\hline & Ford Organizing Dispute & Yes & Disputes \\
\hline $10 / 41$ & $\begin{array}{l}\text { Communists in Unions and role in } \\
\text { defense industry strikes }\end{array}$ & Yes & $\begin{array}{l}\text { WWII } \\
\text { Leaders }\end{array}$ \\
\hline $5 / 43$ & Coal Mine Strike & No & Disputés/WWII \\
\hline $2 / 46$ & General Motors Strike & No & Disputes \\
\hline $7 / 47$ & Taft-Hartley Amendments & Yes & Not Classified \\
\hline \multirow[t]{2}{*}{$12 / 48$} & Unions Help Elect Truman & No & Not Classified \\
\hline & Communists in the $\mathrm{CIO}$ & Yes & Leaders \\
\hline $4 / 57$ & McClellan Committee & Yes & Leaders \\
\hline $8 / 57$ & McClellan Committee & Yes & Leaders \\
\hline $1 / 59$ & $\begin{array}{l}\text { Teamster Corruption/Hoffa's Threat } \\
\text { to Organize Police }\end{array}$ & Yes & Leaders \\
\hline $5 / 61$ & Strikes at Missile Sites & No & Disputes \\
\hline $1 / 63$ & Hoffa Indictment & No & Leaders \\
\hline $12 / 72$ & UMW Election & No & Leaders \\
\hline $8 / 81$ & PATCO Strike & Yes & Disputes \\
\hline $1 / 82$ & Poland Crushes Solidarity & Yes & Not Classified \\
\hline
\end{tabular}

Table 1 summarizes our analysis of major news stories concerning labor relations events that were in close proximity to union approval polling. To qualify as a major news story, the event had to be given at least a half page of space in the national affairs section of two of three major news magazines 
(i.e., Time., Newsweek, or U.S. News and World Report). ${ }^{\text {vii }}$ Stories had to appear in the eight weeks prior to the public opinion polling period. The event or issue did not have to appear in any two of these media outlets in the same week, but merely in the same eight-week period. Several of the events summarized in Table 1 were covered by all three news outlets, and about a half dozen stories received multi-page coverage in all three magazines. ${ }^{\text {viii }}$ Note also that in half of the instances reported in Table 1, Gallup also asked respondents about these events in the same interview period that they assessed union approval.

The information in Table 1 can be sorted into three main categories. The first involves stories about strikes or potential strikes in the defense industry during World War II. The most significant single event occurred in 1943 when John L. Lewis' coal miners were involved in a pay dispute with the Roosevelt administration and the War Labor Board, but our examination of media sources suggests that defense industry strikes were, not surprisingly, somewhat of a national obsession during World War II. Concern about defense industry strikes in the media started in early 1941 and continued to VJ Day. All of the media outlets we studied kept a running account of defense industry strikes during this period and Gallup routinely polled the public on their views of the causes of defense industry strikes (e.g., "Do you think communists in unions are responsible for the strikes in defense industries?" to which 78 percent responded yes in April 1941) and their support for anti-strike measures (e.g., "Should Government forbid strikes in industries manufacturing materials for our national defense . . ?" to which 76 percent responded yes in May 1941). As a result, we include a variable that equals 1 for the years 1941-1945, and 0 otherwise. This variable is expected to have a negative impact on public approval of unions.

In addition to the 1943 UMW strike, several specific labor disputes of national importance took place in proximity to union approval polling. Among the more notable conflicts detailed in Table 1 are the steel organizing drive in 1936 (and beyond), the strike at GM in 1946, and the PATCO strike in 1981. Such disputes are denoted by a dummy variable which equals 1 for the relevant period, zero otherwise. Although we expect this variable to have a negative impact on public approval of unions, this measure is moderately correlated with our strike measure in the sample $\{r=.35, p<.05)$. Thus, media coverage of specific disputes may add little explanatory power to the model beyond what is captured by the general level of strike activity.

Union leaders also captured the national spotlight on a number of occasions.

Dave Beck's appearance before the McClellan Committee in March 1957 made headlines, as did Jimmy Hoffa's appearance later that year. The Teamsters were back in the media spotlight in late 1958, with Hoffa's attempt to oust court-appointed union monitors receiving the most attention. Media coverage of Hoffa's indictment in 1963 was also extensive. Aside from the trials of the Teamsters' leadership, 
three other periods brought labor leaders into the forefront. The first occurred in 1936 when Lewis' feud with hard-line AFL leaders over industrial unionism entered its final stages. The second occurred between 1939 and 1941 when the $\mathrm{ClO}$ was brought under scrutiny for harboring communists that opposed American involvement in the war against Hitler. These fears subsided when the Nazis invaded the USSR in mid 1941 and labor began to rally behind the war effort after Pearl Harbor. The final instance came in 1972 when federal officials supervised the UMW election that led to the ouster of Tony Boyle, the man later convicted of the murder of union rival Joseph ("Jock") Yablonski. The impact of these stories is captured by a dummy variable equal to 1 for the relevant period, zero otherwise. Since each of these stories portrays union leaders in a negative light, it is anticipated that the union leadership variable will have a negative impact on the union approval rating.

A few idiosyncratic labor stories also made the "front page" of the news magazines in our sample. For a variety of reasons, including the nature of the stories and the limited number of observations in our sample, they are not included in the analysis. The first involves the passage of TaftHartley over Truman's veto in July of 1947; the second involves the perception that organized labor's vote was crucial to Truman's re-election in November of 1948. The final event involves the crushing of Solidarity by Poland's communist government in late 1981, early 1982. While not a story about American labor unions. Solidarity may have reminded the American public of the role unions can play in preserving a pluralist society.

\section{Time Trend}

Finally, our analysis of media reporting of labor relations events uncovered a significant change in reporting over time. In the media outlets we surveyed, stories about labor moved from the front page (national affairs section) in the 1930s to 1950s, to the labor page in the 1960s and 1970s, to the business page in the 1980s. Commentators have noted a similar trend throughout the print media (Grimes, 1987, p. 53; Mort, 1992; Schmidt, 1993). In fact, Hoyt (1984, p. 71) suggests that newspapers have cut back on labor reporters and many have stopped covering organized labor. In addition, Goldman and Rajgopal (1991, p. 25) suggest that "as editors gave labor coverage less primacy and financial resources for hiring labor journalists dwindled, the prestige associated with the labor beat also declined." In Hoyt's (1984, p. 71) terms, "Today the labor writer is a tired guy without much history or background, who doesn't go to the factories. Reporters don't understand the language, texture, or history of labor relations. They just don't know what to ask." In short, both the quality and quantity of labor reporting 
has declined. Coupled with the decline in the percentage of respondents who have direct experience with labor unions since the mid 1950s, it seems plausible to suggest that individuals surveyed in the first few decades under study were more informed about unions than those queried in the last few decades under study.

Thus, opinions about labor unions in the latter years of our sample may be "pseudo-opinions" top-of-the-head responses that people make with little or no thinking (Graber, 1982) - rather than the expression of an opinion developed in the wake of informed discussion. Just how a rise in pseudoopinion might influence the union approval rating is difficult to surmise. It seems plausible to suggest, however, that absent specific information about unions, individuals may generalize their beliefs about other organizations to unions. For example, the belief that many business leaders are corrupt may lead to the belief that many union leaders are also corrupt. It is clear from polling data that unions are by no means the only institution to experience declining public support in the 1960 to 1980 period (Lipset and Schneider, 1987). In fact, Lipset and Schneider (1987, p. 2) report a ripple effect across institutions, during this period with a lack of confidence in government spilling over onto other significant institutions, such as business and labor. We proxy this effect by including a linear time trend (measured in months July $1936=0$, July $1991=660$ ) in the model. This variable captures any monotonic influence on public approval not explicitly captured elsewhere in the model.

In sum, our model hypothesizes that public approval of unions is influenced by individual beliefs concerning union attributes. These attributes are viewed positively or negatively by individuals and contribute in an additive fashion to a global assessment of organized labor. Salient union characteristics include the degree of strike activity, the union wage advantage, media accounts of labor disputes, and reports on union leaders. Information on the state of the national economy, the WWII period, and a linear time trend are also included in the model. Although not strictly union characteristics, macroeconomic outcomes and WWII bear a relationship to perceptions of external union power, while the linear time trend is meant to proxy for the general decline in the popularity of all institutions. The model does not present an exhaustive list of union characteristics or proxies that may be important to the public's assessment of organized labor, but it does touch on four of the five dimensions identified by Craft and Abboushi (1983). Only information on membership identity - the popular perception regarding the characteristics and orientations of union members - is absent from the model. ${ }^{\text {ix }}$ 
Table 2

Determinants of Union Approval Rating: 1936-1991

(standard error)

\begin{tabular}{|c|c|c|c|}
\hline & Approve & Disapprove & Net \\
\hline Intercept & $\begin{array}{l}67.13 * * \\
(2.92)\end{array}$ & $\begin{array}{l}19.59 * * \\
(2.23)\end{array}$ & $\begin{array}{l}47.54^{* *} \\
(4.41)\end{array}$ \\
\hline Union Wage Differential & $\begin{array}{l}1.56^{* * *} \\
(0.33)\end{array}$ & $\begin{array}{l}-1.29 * * \\
(0.25)\end{array}$ & $\begin{array}{l}2.85^{* *} \\
(0.50)\end{array}$ \\
\hline $\begin{array}{l}\text { Union Wage Differential } \\
\text { Squared }\end{array}$ & $\begin{array}{l}-0.04 * * \\
(0.01)\end{array}$ & $\begin{array}{l}0.04^{* *} \\
(0.01)\end{array}$ & $\begin{array}{l}-0.08^{* *} \\
(0.02)\end{array}$ \\
\hline Unemployment Rate & $\begin{array}{l}-0.41^{* *} \\
(0.16)\end{array}$ & $\begin{array}{l}0.49^{* *} \\
(0.12)\end{array}$ & $\begin{array}{l}-0.90 * * \\
(0.24)\end{array}$ \\
\hline Inflation Rate & $\begin{array}{l}-0.21 \\
(0.17)\end{array}$ & $\begin{array}{c}0.16 \\
(0.13)\end{array}$ & $\begin{array}{l}-0.37 \\
(0.26)\end{array}$ \\
\hline $\begin{array}{l}\text { Days Lost to Strikes } \\
\text { (in millions) }\end{array}$ & $\begin{array}{l}-0.05 \\
(0.20)\end{array}$ & $\begin{array}{l}0.42^{* *} \\
(0.15)\end{array}$ & $\begin{array}{l}-0.47 \\
(0.30)\end{array}$ \\
\hline $\begin{array}{l}\text { Media Reports on } \\
\text { Labor Disputes }\end{array}$ & $\begin{array}{l}-0.98 \\
(1.75)\end{array}$ & $\begin{array}{c}0.92 \\
(1.33)\end{array}$ & $\begin{array}{l}-1.91 \\
(2.64)\end{array}$ \\
\hline $\begin{array}{l}\text { Negative Media Reports } \\
\text { on Union Leaders }\end{array}$ & $\begin{array}{l}-2.87^{*} \\
(1.41)\end{array}$ & $\begin{array}{c}0.65 \\
(1.08)\end{array}$ & $\begin{array}{l}-3.52 \\
(2.13)\end{array}$ \\
\hline World War II & $\begin{array}{l}-3.87 \\
(2.53)\end{array}$ & $\begin{array}{l}7.26^{* *} \\
(1.93)\end{array}$ & $\begin{array}{c}-11.12 * * \\
(3.83)\end{array}$ \\
\hline Time & $\begin{array}{l}-0.03^{* *} \\
(0.00)\end{array}$ & $\begin{array}{l}0.02^{* *} \\
(0.00)\end{array}$ & $\begin{array}{l}-0.05^{* *} \\
(0.01)\end{array}$ \\
\hline$R$-Square & .78 & .86 & .86 \\
\hline$N$ & 32 & 32 & 32 \\
\hline Durbin-Watson & 2.03 & 1.83 & 1.97 \\
\hline
\end{tabular}

${ }^{*}(* *)=$ significant at the $.10(.05)$ level, two-tail test.

V. Results

Ordinary least squares results for the union approval and union disapproval equations are reported in Table 2. ${ }^{\times}$Results using net union approval as the dependent variable are also presented so readers can make comparisons with Edwards and Bain (1988). Note that the coefficients in the net approval equation are simply the difference between the coefficients in the union approval and disapproval equations. The results in Table 2 suggest that the influence of the union-nonunion wage differential on public approval is nonlinear. In each instance the coefficients carry the expected sign and achieve standard levels of statistical significance. The coefficients imply that union approval is maximized when 
the union wage advantage is between 19 and 20 percent. Union disapproval is minimized when the union wage differential is between 16 and 17 percent. Net union approval is maximized between 18 and 19 percent, all else constant.

The results also provide some support for the hypothesis that unions take some of the credit (or blame) for existing economic conditions. The national unemployment rate has a negative and statistically significant effect on both union approval and net approval and has a positive and statistically significant impact on disapproval. The results for the national inflation rate are less impressive. Each coefficient has the proper sign, but none attains standard levels of statistical significance.

Days lost to strikes exhibit a particularly interesting pattern. Only the coefficient in the union disapproval equation reaches standard levels of statistical significance. In addition, the coefficient in the union approval equation is smaller than its standard error. This pattern of results suggests that increases in strike activity may turn those expressing no opinion about unions into trade union critics, but may have little impact on union supporters most of whom may view strikes as a necessary evil. ${ }^{x i}$ Note that the impact of strike activity on union disapproval is obscured in the net approval equation $(p>.13)$.

As a group, the results with respect to news stories on major labor relations events are unimpressive. Holding the level of strike activity constant, national media coverage of specific disputes appears to have little or no effect on public opinion. ${ }^{\text {xi }}$ Each coefficient for this variable is small relative to

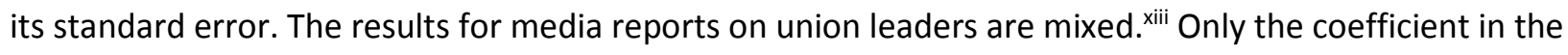
approval equation achieves a standard level of statistical significance. .iv $^{\text {in }}$

In contrast, the coefficients on the World War II variable are larger than their standard errors and two achieve standard levels of significance. These results are consistent with our hypothesis that union popularity suffered because of concerns over the possible interruption of war production. Yet, because Gallup used a slightly different question prior to 1947, it is difficult to cleanly separate out any war effect from any potential question wording effect. Estimating models that include a dummy variable for the difference in question wording results in a positive and significant $(p<.05)$ coefficient for this measure in the disapproval equation, but a negative and insignificant $\{p>.50$ ) coefficient in the approval equation. The WWII measure becomes statistically insignificant across the three equations. Thus, some care should be taken in interpreting the result in Table 2 as unequivocal indication of a "war" effect.

Finally, the results suggest a strong linear decline in support for labor unions over the period under study. Holding other factors constant, these coefficients suggest that union approval is almost 20 points lower (-.03*660) and disapproval over 13 points higher $(.02 * 660)$ in July, 1991 than in July, 1936. 
A rise in pseudo-opinion may be one explanation for this phenomenon, but other unmeasured factors correlated with time may also be at work. ${ }^{\mathrm{xv}}$

\section{Discussion}

Our results confirm and extend the literature on public approval of unions. Consistent with past efforts, our results support the notion that union popularity is influenced by macroeconomic conditions and strike activity. As major economic institutions, unions are held partly responsible for the state of the national economy. Unions also pay a price for engaging in strikes. Yet, our results suggest that the impact of strikes on U.S. public opinion may come less from a loss in support for unions (i.e., approval), than from a rise in opposition (i.e., disapproval) to them. Strikes appear to push some of the "no opinion" respondents into the disapproval camp.

But, our results suggest that other factors also influence public approval of labor unions. Most notable is the effect of the union-nonunion wage differential on union popularity. This finding is consistent with more qualitative efforts that note that support for unions is grounded in the view that they are necessary to advance worker interests (Bok and Dunlop, 1970, p. 13). ${ }^{\text {xi }}$ However, our estimates also suggest that large wage differentials between union and nonunion workers lower public support for trade unions. Taking our estimates at face value, public approval declines once the union-nonunion wage differential exceeds 20 percent.

Support is also found for the view that union goals and activities are evaluated in particular national contexts. The results for our WWII variable suggest that national crises may cause the public to view unions in fundamentally different terms, with important consequences for union popularity.

Together these results suggest that unions must walk a fine line in the pursuit of public approval. Unions are popular because they are effective, but in the public's view unions can push their economic gains too far, leading to rising levels of public disapproval. Even the attainment of modest wage gains may bring rising public disapproval if such gains require resort to confrontational tactics. To the extent that unions must use confrontation tactics to achieve their goals, or have members whose aspirations exceed public perceptions of fair wage gains, unions cannot please all of the people all of the time.

A potential bright spot for unions may be found in the results for negative media stories about union leaders. The commonly held view that organized labor's public image has suffered greatly from the actions of a few union leaders finds only modest support in the data. Our estimates suggest that, on 
average, a negative story about union leaders reduces the union approval rating by only about 3 percentage points (Table 2, column 1). But, this evidence is insufficient to justify a conclusion that beliefs about union leaders have little or no impact on union popularity. News stories may not have had the short-term impact on public perceptions of union leaders implied by our empirical specification. Public perceptions of union leaders may have been relatively fixed over the period under study and insensitive to the revelations in major news stories. Thus, a stable subset of the public may hold negative (or positive) views of union leaders and these views may reduce (or increase) the likelihood that individuals approve of unions in general. ${ }^{\text {xvii }}$ Efforts to examine changes in aggregate public approval over time would not capture such an effect. Alternatively, negative stories about union leaders may have a cumulative effect on public opinion, increasing negative perceptions of union leaders over time. It is also possible that there has been a general shift in the importance of media influence on public opinion. The public may have come to place greater emphasis on major stories about union leaders as the availability of alternate sources of information about unions (e.g., first hand experience, accounts from friends and co-workers) has declined. Note that the presence of either a cumulative effect of news stories on public beliefs about unions or an increase in the weight given individual stories about union leaders in the determination of union approval over time could contribute to the negative and significant coefficient on our linear time trend variable.

Finally, collection of more systematic data is necessary if our understanding of public opinion about unions is to be improved. The irregular and infrequent intervals at which observations are available limit the statistical power of our tests. Aside from concerns about sample size, our analysis in Table 1 shows that over half of the observations are in close proximity to what we have defined as a major news story about unions. Obviously, the number of events that influenced public opinion near the time when polling took place may differ from the number noted in Table I. Yet, the frequency with which we uncovered such news stories raises the possibility that the data in Figure 1 highlight public responses to relatively idiosyncratic events (i.e.. increases "noise"), making it more difficult to detect systematic influences on public approval. Only by sampling public opinion at regular intervals, as is done in the U.K., can we be confident that we have an accurate picture of the determinants of public approval of unions over time.

In addition to improving the regularity of data collection, better efforts must be made to adequately assess respondents' beliefs about unions. Questions should be designed to tap beliefs about a wide range of union attributes and should inventory the information sources respondents use to form beliefs about unions. Such polling would permit more detailed micro-level examinations of the relative 
contribution of various beliefs in the determination of union approval and whether these contributions change over time. Such an effort would also provide insights into the formation of beliefs about unions and whether such beliefs are easily influenced by changes in union attributes or information sources about unions.

\section{REFERENCES}

ABC News and Washington Post. Poll of Public Opinion on Current Social and Political Issues. Radnor, Penn.: Chilton Research Services, January 1982, September 1986.

AFL-CIO Committee on the Evolution of Work. Changing Situation of Workers and Their Unions. Washington, D.C.: AEL-CIO, 1985.

Anonymous. "More Americans Say Yes to Unions: Gallup Poll Reports Continuing Rise in Approval Rating." AFL-CIO News 33 (August 27, 1988), pp. 1, 8.

Ashenfelter, Orley, and John H. Pencavel. "American Trade Union Growth, 1990-1960." Quarterly Journal of Economics 83 (August 1969): 434-48.

Blanchflower, David B., and Richard B. Freeman. "Unionism in the United States and Other Advanced OECD Countries." Industrial Relations 31 (Winter 1992): 56-79.

Bok, Derek C, and John T. Dunlop. Labor and the American Community. New York: The Rockefeller Brothers Fund, 1970.

Cantril, Hadley. Public Opinion: 1935-1946. Princeton, N.J.: Princeton University Press, 1951.

Craft, James A., and Suhail Abboushi. "The Union Image: Concept, Programs, and Analysis." Journal of Labor Research 4 (Fall 1984): 299-314.

Edwards, P. K., and George Sayers Bain. "Why Are Trade Unions Becoming More Popular? Unions and Public Opinion in Britain." British Journal of Industrial Relations 26 (November 1988): 311-26.

Fishbein, Martin, and Icek Ajzen. "Attitudes and Voting Behavior: An Application of the Theory of Reasoned Action." In G.M. Stephenson and J. H. Davis (eds.) Progress in Applied Social Psychology. New York: John Wiley, 1981, pp. 253-314.

Gallup, George H. The Gallup Poll. Wilmington, Del.: Scholarly Resources, various years.

Goldman, Robert, and Arvind Rajgopal. Mapping Hegemony: Television News Coverage of Industrial Conflict. Norwood, N.J.: Ablex, 1991.

Graber, Doris A. "The Impact of Media Research on Public Opinion Studies." In D.C. Whitney and E.Wartella (eds.) Mass Communications Review Yearbook. Vol. 3. London; Sage, 1982.

Grimes, John A. "Are the Media Shortchanging Organized Labor?" Monthly Labor Review 110 (August 1987): 53-4.

Heshizer, Brian. "Unions and Public Opinion: Why the Declining Relationship?" Labor Studies Journal 9 (Winter 1985): 254-70.

Hoyt, Michael. "Is the Press Anti-Labor? Or Just Out of Touch." Labor Research Review 4 (Summer 1984): 69-80.

Johnson, George. "Changes Over Time in the Union-Nonunion Wage Differential in the United States." In J. J. Rosa (ed.) The Economics of Trade Unions: New Directions. Boston: Kluwer-Nijhoff, 1984, pp. 3-19.

Keegan, Carol. "How Union Members and Nonmembers View the Role of Unions." Monthly Labor Review 110 (August 1987): 50-1.

Kochan, Thomas A., Harry C. Katz, and Robert B. McKersie. The Transformation of American Industrial Relations. New York: Basic Books, 1986. 
Krahn, Harvey, and Graham S. Lowe. "Public Attitudes Towards Unions: Some Canadian Evidence." Journal of Labor Research 5 \{Spring 1984): 151-64.

Kirkland, Lane. "Using Television to Reach Workers." AFL-CIO News 35 (May 14, 1988), p. 3.

Lipset, Seymour Martin. "Labor Unions in the Public Mind." In S. M. Lipset (ed.) Unions in Transition. San Francisco: Institute for Contemporary Studies, 1986, pp. 287-322.

and William Schneider. "The Confidence Gap During the Reagan Years: 1981-1987." Political Science Quarterly 102 (Spring 1987): 1-23.

-------The Confidence Cap: Business, Labor and Government in the Public Mind. New York: Free Press, 1983.

Marsh, David. "Public Opinion, Trade Unions and Mrs. Thatcher." British Journal of Industrial Relations 28 (March 1990): 57-68.

Mort, Jo-Ann. "How the Media "Cover" Labor." Dissent 39 (Winter 1992): 81-5.

Raskin, A.H. "Newspaper Reporting of Trade Unionism." In James L. Stern and Barbara Dennis (eds.) Trade Unionism in the United States: A Symposium in Honor of Jack Barbash, Madison Wise: Industrial Relations Research Association, 1981, pp. 225-40.

Roiser, Martin, and Tim Little. "Public Opinion, Trade Unions and Industrial Relations." Journal of Occupational Psychology 59 (Winter 1986): 259-72.

Stepina, Lee P., and Jack Fiorito. "Toward a Comprehensive Theory of Union Growth and Decline." Industrial Relations 25 (Fall 1986): 248-64.

Schmidt, Diane E. "Public Opinion and Media Coverage of Labor Unions." Journal of Labor Research 14 (Spring 1993): 151-64.

U.S. Bureau of Labor Statistics. Handbook of Labor Statistics. Washington, D.C: U.S. Government Printing Office, 1983, 1989.

-------Monthly Labor Review, various issues.

Walsh, Geoff. "Trade Unions and the Media." International Labour Review 127 (May-June 1988): 205-19.

\footnotetext{
' Questions that evoke a general assessment of trade unions may provide little direct information on the basis for union support (Marsh, 1991, p. 59), but few would argue that properly done opinion polls fail to accurately report such global assessments. Instead, debates about the validity of such measures center on the definition of public opinion. Those who define public opinion in narrow terms - carefully considered views that come to the attention of decision makers - have greater reservations about the information contained in such polls. These objections are succinctly stated by Roiser and Little (1986, p. 271) who note: "While public opinion is an efficient measuring device, all it does is aggregate private views. These views may be superficial, lacking in intensity, have largely a conversational function and be poor predictors of behavior." We share these reservations and caution against efforts to draw too close a nexus between variations in opinion polls and variations in industrial relations outcomes. Yet, such polls provide at least crude information on public views about unions. Public views, as expressed in such polls, do change over time. And given the attention paid to such polls by the press, unions, and employers, it is difficult to argue that they have no significance.

ii Gallup data show that a majority of the public routinely supports cooling-off periods prior to strikes (e.g., 78 percent in 1945, 89 percent in 1949), limits on strike duration (e.g., 51 percent in 1965, 54 percent in 1966, 68 percent in 1967, 69 percent in 1968), and private sector dispute resolution procedures (e.g., 78 percent in 1945, 59 percent in 1959). More extreme measures have received support among a significant minority of the public. For example, in 1941, 37 percent agreed with a proposal that would jail strikers in the defense industry for up to one year. In 1966, 39 percent agreed that third parties should be able to sue striking unions or management to recover economic losses.

iii Starting in 1982, the Bureau of Labor Statistics limited reporting of labor disputes to those involving
} 
1,000 or more workers. We calculated the ratio of days lost to strikes involving at least six workers (the pre-1982 standard) to days lost to strikes involving at least 1,000 workers for the years 1970 to 1981 . The average of this ratio is 1.57 (standard deviation $=.15$ ). Total days lost to strikes in any month after December 1981 were then estimated by multiplying the reported figure for strikes involving at least 1,000 employees by 1.57 .

iv Recall that the interview period varies from January to December in the data. Using calendar-year strike measures when the interview period is in December assumes individuals base their assessments of unions on past union behavior. Using calendar-year strike measures when the interview period is in January assumes that individuals estimate the degree of strike activity in the upcoming year when forming their assessments of unions. Both past strike activity and expectations about future industrial conflict may play a role in determining union approval, but a theoretically consistent operationalization is warranted. Edwards and Bain (1988) benefit from a fixed interview period: The question is almost always asked in August. Thus, by using strike measures for the calendar year in which the interview takes place, they implicitly assume that respondents weigh both the experience of the past 7-8 months and their expectations about industrial conflict in the next 4-5 months when forming a general assessment of labor unions.

$\checkmark$ Blanchflower and Freeman (1992) estimate the union-nonunion wage differential at 22 percent for 1985-1987. We use this figure for years 1985 through 1991. For years 1981 and 1982, we use the mean for the 1975-1980 and 1985-1987 periods, 26 percent.

vi Lipset and Schneider (1987, p. 19) note that, despite concession bargaining and a decline in inflation in the early 1980s, two Opinion Research Corporation polls show 58 percent of the public in 1982 and 57 percent in 1986 agreed that "Employers should start taking a harder line with unions than they have in the past."

vii The sole exception to this rule involves the UMW election in 1972. During December, 1972, this story received a page of coverage in the national affairs section of Time, a three page story in the labor section of U.S. News and World Report, and two stories of about a half page each in Newsweek's business section. Given the changes in media reporting of labor stories over the years, the extent of coverage given to this event seems to warrant its inclusion as a major news story.

viii Stories that did not meet our space requirements during the eight-week event period are viewed as background noise." Some individuals may have used the information in these stories to form opinions about unions, but it is unlikely that these stories influenced enough individuals to have an impact on the aggregate public approval rating. Thus, one assumption of our approach is that the public has a fairly short memory when it comes to labor stories and that changes in public opinion are the result of a few significant labor relations events rather than the cumulative effect of many small stories. A second assumption is that the information reported in our sources is representative of the stories covered by the media more generally. Many individuals may not have read any of the magazines we surveyed, but it seems likely that our rules concerning significant news stories uncovered only those events that received considerable attention by all media outlets (print, radio, and, eventually, television).

${ }^{i x}$ The omission of trade union density from our model may surprise some readers. There is evidence to suggest that union members hold different views from nonmembers concerning various union attributes (e.g., Keegan, 1987) and that union members, on average, have higher general assessments of unions than nonmembers (e.g., Lipset, 1986, p. 410). However, incorporation of union density into a model of aggregate public approval brings both endogeneity and simultaneity concerns. As noted, Lipset (1986) argues that public opinion is an important determinant of trade union growth. In addition, union growth is typically viewed as a function of the business cycle (e.g., Ashenfelter and Pencavel, 1969). The small number of observations available for our analysis precludes any attempt to estimate a set of simultaneous equations. Thus, we prefer a model that excludes union density from the empirical specification. The model specified in the text can be viewed as a reduced-form equation in which it is implicitly assumed that union density is largely a function of the business cycle (inflation and unemployment).

${ }^{x}$ The Durbin-Watson statistics reported in Table 2 all fall within the inconclusive range for the two-sided test at the 5 percent significance level. Yet, given the irregular intervals at which public polling took place, it is difficult to place confidence in a test for first order autoregression.

${ }^{x i}$ Regressing the percent of respondents expressing no opinion to the union approval question on the independent variables used in the analysis reported in Table 2 yields a negative $(-.37=-[.42-.05])$ and significant $(f=1.95, p<$ .10) coefficient for the strike activity measure. This is the only coefficient achieving conventional levels of statistical significance in the no opinion equation. 
${ }^{12}$ To examine the impact of multicollinearity, we estimated models which alternately excluded one of these variables. Results from the equation which excluded the strike activity measure are as follows:

$\begin{array}{lccc} & \text { Approve } & \text { Disapprove } & \text { Net } \\ \text { Media Reports on } & -1.12 & 2.12 & -3.23 \\ \text { Labor Disputes } & (1.61) & (1.44) & (2.58)\end{array}$

The only statistical inference that differs from that reported in Table 2 concerns the coefficient on the negative media reports on union leaders variable. The coefficient remains negative, but is marginally significant $(p<.10)$ in the net approval equation.

Results from the equation which excluded the media coverage on labor disputes measure are as follows:

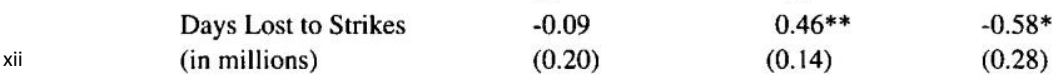

xiii Models were also estimated that included dichotomous variables for each of the three major news stories not classified in Table I. Only the coefficient on the variable denoting news stories on Solidarity in the union approval equation exceeded its standard error. In all three equations, a test of the joint hypothesis that the three coefficients of interest were equal to zero could not be rejected at conventional levels of statistical significance. xiv Direct comparison of the results for our media-related variables with those reported by Schmidt (1993) is not possible. Schmidt's measures are designed to assess the degree to which media reporting on unions is strike-driven and how this influences public opinion. Our approach uses media sources as a means of identifying specific industrial relations events that were salient at the time Gallup polling took place. Given the different approaches and time periods under study, different results are not surprising. We did however estimate models for the 1947-1985 period that incorporated one of Schmidt's measures of strikecentered media coverage of unions (Schmidt 1993, Figure 3, p. 157). A number of results are noteworthy. Regressing each of the three dependent variables on only the lagged media coverage variable produces parameters that carry the proper sign and achieve standard levels of statistical significance in each instance. However, estimating models that more closely approximate those in Table 2 yields parameters for the lagged media coverage variable that consistently fail to achieve standard levels of statistical significance. In fact, our media-related variables outperform the Schmidt variable in similar equations in this period. In general, both the media reports on labor disputes variable and the negative media reports on union leaders variable have parameters that carry the proper sign and achieve standard levels of statistical significance for this period. In addition, the parameters on the days lost to strikes variable generally fail to reach standard levels of statistical significance in these equations. All of this suggests instability in these parameters across periods and raises the possibility that the major influences on public opinion about unions have changed over time. Results of the analyses described above are available from the first author on request.

${ }^{x v}$ Models that included a variable measuring union density (see footnote 9), produced the following results for the variable of interest.

xvi We cannot reject the possibility that public support of labor unions contributes to the union wage differential. This is particularly problematic because our measure of the union wage differential spans five-year periods, while at times public opinion is measured near the beginning of the five-year period. However, the U-shaped relationship between public approval and the union wage differential reported in Table 2 makes it unlikely that the impact of public approval on the union wage differential is the dominant influence underlying our results.

xvii No consistent information on public beliefs about union leaders exists for the entire period under study, but Bok and Dunlop (1970, p. 16) note that public perceptions of union corruption predate the McClellan Committee Hearings by a number of years. In addition, evidence collected since the mid-1970s exhibits remarkable stability. In the eight times between 1976 and 1991 the public has been asked to rate the honesty and integrity of union leaders, the percentage responding "high" or "very high" has never exceeded 15 percent or fallen below 12 percent. Furthermore, in both the 1982 and 1986 ABC News-Washington Post polls, respondents were asked whether they believed "most national labor unions had ties to gangsters and hoodlums," or whether such ties had been "greatly exaggerated." An almost identical 37 percent (36.9 percent in 1982 and 37.1 percent in 1986) responded that they believed most national unions had ties to gangsters. In both years a negative and statistically significant relationship exists between individuals' views on union corruption and approval of trade unions (1982: $r$ 
$=-.26, p<.001 ; 1986: r=-.28, p<.001)$. This result suggests that negative beliefs about union leaders had a small, but relatively stable influence on union approval during this five-year period. 